\title{
Politics, Power and Agency in Early Childhood Care Education In
}

\author{
Nigeria \\ Domike Grace Chikadibia* and Undie,Ushinyin Josephine* \\ *Department of Curriculum and Teaching, Faculty of Education, University of Calabar, Calabar, Nigeria \\ ** Department of Early Childhood Care Education, Cross River State College of Education, Akamkpa- Nigeria
}

\begin{abstract}
:
Politics, power and agency are very important aspect of early childhood care educational management practices in Nigeria in the sense that education is an off-shoot of the political system indulged with power and agency to promote the development of ECCE. Politics fashions education and education modifies politics, powers are imposed on stakeholders of education for proper monitoring and execution of ECCE projects. This paper examines the concepts of politics, power and agency in early childhood care education and the relationship between politics, power and agency and education in Nigeria.
\end{abstract}

Keywords: Politics, Power, Agency, Early Childhood Care, Education

DOI: $10.7176 / \mathrm{JEP} / 10-10-14$

Publication date: April $30^{\text {th }} 2019$

\section{Introduction}

Early years in life are widely accepted as the most important period during which children experience cognitive,language, perceptual, socio-emotional and motor development which they will need for future achievements andsocial functioning. This informs the reason why the period of the early years need to be handled with all specialand detailed attention. Estes (2004) has described the early years as a remarkable period of growth anddevelopment in the lives of children. In their submission, Oduolowu and Olowe (2011) noted that the early yearsof children are years of extreme vulnerability and tremendous potentials, during which adequate protection, careand stimulation are essential to provide the foundation for well-being and development. In providing thisfoundation during the early years, Early Childhood Education (ECE) becomes a key actor.

The foundation of education of the child is the early childhood care education that forms an integral part of his or her early education which may be formal or informal, that is given in an educational institution to children aged 0 to $5+$ prior to their entering the primary school. This educational level of the child provides for the physical, motor, health, nutritional, intellectual, aesthetic, emotional and social development of the preschool child. If child education can provide these vital necessities which are fundamental in human life, it is not therefore unlikely to have an important and strong relationship with the pupils' performance at the primary school level and perhaps at the secondary and tertiary levels.

The Universal Basic Education Act of 2000 cites Early Childhood Care Education (ECCE), which has to do with pre-primary education given to children between ages 0 to 5 years, as an integral part of basic education. It represents the first important step in achieving the goals of Education for All (EFA). Since it is the foundation for a life-long education, government is expected to be actively involved in providing it for the younger children. Evidence on the ground has shown that parents, private individuals, religious bodies constitute the largest proprietorship of ECCE, while government agencies provide a partly 10\%. Adenipekun (2004) notes that this abysmally low government's participation in proprietorship of day care centres and nursery schools deny the poor, disadvantaged and marginalized groups' access to ECE.

It is pertinent to note that all Early Childhood Care activities and programmes are geared towards giving positive early experiences to children. This further underscores the importance of early years. The paramount importance of the early years is widely acclaimed in various international documents and developmental goals such as United Nations Convention on the Right of the Child, African Charter on the Rights and Welfare of the Child, Millennium Development Goals (MDGs) and Education for All (EFA) goals among others. The government of Nigeria is among the member states that ratified these documents and goals, and this has made the government to come up with various interventions which are geared towards providing quality Early Childhood Care Education for Nigerian children.

\section{Politics in early childhood care education}

The term politics has been well articulated by educators and social scientists on the subject. They have both agreed that politics is not just restricted to political parties but it is also there in the Nigerian banks, markets, educational institutions, churches, sports, business, military establishment commercial and industrial factors of 
our economy. According to the American political scientist, Harold Lasswell(1936), politics is defined as who gets what, when and how. This definition can easily be remembered because it is in the form of a slogan. Furthermore, it represents reality to a good extent especially in Africa. Politics involves the allocation of scarce social, economic and cultural resources to individuals, groups, regions and classes.

As we have been witnessing during the current election cycle, Nigerian voters are frustrated with elected officials and candidates for public office. Voters across the country do not believe candidates are addressing their priorities, and candidates would not be wise to listen to these frustrations and acknowledge them. Education is an issue that serves as a linchpin for many of the other issue concerns of voters, such as job security, economic opportunity, wage stagnation and economic mobility. Helping families and communities provide children with high-quality early education from birth to age five has emerged as a family issue which the vast majority of Democrats, Republicans and independents can agree upon and urge action. Agagu(2010).

In the past, politicians and educators perceived their roles as completely separate and independent. The myth had been propagated that politics and education do not mix. The reality however, is that there is no apolitical education system and, no educational system can be separated from political system that engenders and supports it. The proposition here is that considering their societal responsibilities and objectives, education and politics are inextricably related. Nwankwo(2014).

The politics adopted by any educational system are essentially drawn by the government in power (the political system). Early childhood care educational policies are therefore those guidelines expedient both for political socialization and for national socio-economic and cultural development. Every government or political party is conscious that to ensure its political, social and economic success, the schools must be involved in the promotion of the interests of the governing power. Some handy examples of how the political system used the education system to promote the political programmers may be drawn Hitler's Germany, Lenin's Russia Victorian England, the Mao-Tse Tong China, the French Revolution and some Military Governments in Africa. On the other hand, the education system and educators need the support and patronage of the ruling political system, the public and other governmental agencies in order to carry out their functions of socialization and training of the people. No educational system can survive without the financial support and protection of the government in power. Therefore, by having to unavoidably depend on successive governmental support and protection, education finds itself used for the promotion of political creeds and social views of successive government and political leaders.Nwankwo(2014).

According to Ogbonnaya (2009), politics has always been at the forefront of education in Nigeria. For instance, there was a partnership arrangement between church and state in education. Under the partnership arrangement, the missionary societies used the establishment of schools for purposes of conversion, the production of lay readers, catechists, teachers and literate personnel for commercial houses. When the British colonial government became involved in education, its own purpose was mainly to produce literate and clerical staff who would keep the colony in a subordinate position for continued exploitation. The Nigerian government believed very much in the education of her citizens. This can be illustrated from her use of education for social, economic and political development, for equalization of educational opportunities and for ethnic harmony.

\section{Power in early childhood care education}

Education per se is power, or so educators truly believe. Education is able to influence politics, the business environment, faith, teachers and parents, as well as the media. Throughout time, power in the field of education has been attempted to be realized, demonstrated, proven and imposed by a variety of actors: politicians, public figures, the clergy, business people, warlords, teachers, parents, and the mass media among others. The power structure has changed according to the political system, market economy, tradition, and even fashion.

Therefore, this paper will focus on the following issues: how does power - usurped or self-proclaimed, appointed, democratically or naturally won, act upon the field of early childhood care education? How has power affected teachers and their education? How does teacher education affect power? How has power and education affected childhood and adolescence and has it influenced the lived identity of men and women? How is power reflected in curriculum, textbooks, and teaching aids? How do the educational sciences serve power, and how do they legitimize power? How can we identify and explain the relationship between power and education? How possible in the field of education is it to support, restrict, stimulate and deny through power? Does power encourage resistance and how does this occur? Is it possible to resist power in education?

Changes in living conditions, social relationships and family structures have led to changes in access,availability and provision of services and care for young children. Although child welfare has been atraditional concern, in many countries resources and attention have been diverted to more pressingneeds or new governmental priorities. These changes have forced voluntary agencies, NGOs, localcommunities and governmental bodies to work together and better target actions for youngchildren. Agagu(2010). 
Under the limitations of a constrained budget and severe demands for mainstream services, the government has recognized the need to be most efficient in its targeting of services, and to guide and support NGO and private initiatives in this area. At national level, significant progress has been made in recognizing the place of NGOs andcommunity organizations in national development, and the role they can play in theimplementation of national social and economic development plans, in various areas including earlychildhood care and education. Many governments have also realized the importance of placingearly childhood on the national agenda, and have consequently adopted policies and measures tohelp improve services for young children and provide better awareness of children's issues amongthe general public. Adesina(2011).

The well-being of young children is the focus of a great number of NGOs and communityassociations throughout Nigeria and environs. These organizations work both at local and nationallevels in all areas of importance to young children and their families, such as health, education,welfare, the law, water and environmental sanitation. They are increasingly being encouraged bygovernments to help implement the extensive social development programmes outlined in nationalsocial and economic development plans.Education, at all levels, is not the responsibility of the State alone. The family, thecivil society at large, the media, all must contribute to provide the necessary servicesand materials, as well as a propitious climate. UNESCO (1993)

Following the adoption of goals for the year 2000 at the World Summit for Children, governmentsin Nigeria have prepared National Policy on Education Programmes of Action to meet these goals. TheseProgrammes of Action reflect provisions in the Convention on the Rights of the Child and includegoals such as $90 \%$ immunization coverage against the most common childhood diseases, halvingchild malnutrition, providing safe water and family planning services to all communities, andensuring that all children have access to basic education. Adesina(2011).

\section{Agency in early childhood care education}

Early Childhood Care and Education is a service with consistently global demand. The United Nations Educational, Scientific and Cultural Organization (UNESCO) has defined 'Early Childhood' as the period from birth to eight years old. UNESCO's strong advocacy for Early Childhood Care and Education is founded on the basis that this stage of a child's life is one of highly receptive, foundational learning. The organization promotes this fact, as the rationale for ECCE implementation by its member nations. Acting as an international pressure group, UNESCO calls for ECCE programmes that attend to health, nutrition, security and learning and which provide for children's holistic development.

In the year 2010, UNESCO organized the first ever World Conference on Early Childhood Care Education and development, in Moscow, Russia. The Conference included Heads of Government and key stakeholders of the international ECCE arena. The flagship product of this conference was the 'Moscow Framework for Action and Cooperation: Harnessing the Wealth of Nations'. It is from this framework that UNESCO and its member nations work collaboratively, to develop ECCE programmes globally. Nigeria has been a member state of the United Nations since, and through the work of UNESCO, continues to benefit from these development initiatives, particularly those aimed at Early Childhood Care and Education. Adesina(2011).

Early Childhood Care and Education (ECCE) in Nigeria is administered by the Ministry of Education. A National Commission for UNESCO in Nigeria monitors adherence to UNESCO's standards and provides assistance for local ECCE development, as needed. The current Minister of Education MallamAdamuAdamu, also serves as President of this Commission.

ECCE in Nigeria is offered by both government owned / government-assisted and privately owned centres for children between the ages of 0 to 5 . Defined in its local context, 'ECCE' refers to a wide range of programmes aimed at the physical, cognitive and social development of children before they enter primary school, while 'ECCE Centre' refers to all facilities providing learning support, care and development services to children from 0 to children under six years of age. Crosser(2012).

Government has identified the provision of universal ECCE as a national development priority. This initiative is focused on making ECCE available to all children in Nigeria within the ECCE age bracket. It includes the construction of new ECCE Centres and by facilitating greater public/private sector partnership. According to a 2012 news release by the Federal Government of Nigeria, more teaching jobs will be created through the N-Power programme initiatives as the Ministry moves forward to achieve Universal Early Childhood Care Education. A total of 40,000 ECCE teachers will be required within two to three years. FGN(2016). These emerging job vacancies will need to be filled by appropriately qualified, skilled persons. As such, the existing gaps between the employer, training provider and job-seeking citizen must be effectively bridged. The Early Childhood Care and Education Sector in Nigeria is comprised of over four thousand (4000) government run/assisted and privately owned ECCE centres. Government's drive to achieve universal access to ECCE is expected to increase the sector's demand for more appropriately trained and qualified persons. 


\section{Conclusion}

Politics, power and agency in Early Childhood Care Education is concerned with attracting, searing and maintaining the welfare of a community, state or nation. It involves laying down principles that guide the state in its operations. It is a device intended for finding solutions to the socio-economic and technological problems of a nation. The relationship between politics, powers, and agencies and education has been discussed and we have come to the conclusion that there is a thin line relationship between politics, power, agency and education. Politics, power and agencyapparently directs education. We have also seen that politics, power and agency has been at the forefront of education in Nigeria.

The role of politics, power and agency in the Early Childhood Care and Education Sectors were discussed and number of issues and concerns were also reported which may potentially affect the quality of ECCE in Nigeria, unless they are addressed.

Nigeria is expected to achieve universal Early Childhood Care and Education in the year 2020. This development will ideally allow all of the nation's children within the ECCE age bracket, to have access to the service. Since the main purpose of this initiative is to ensure inclusion, it would be prudent for government to address the issues concerning children with special needs. Infrastructural expansion must be accompanied by a sufficient and appropriately trained pool of labour that can efficiently deliver an updated, industry-relevant national curriculum. Adesina(2011).

Despite the many issues and concerns voiced with regard to developing the Early Childhood Care and Education Sector of Nigeria, many solutions to these problems were also suggested by the owners and administrators surveyed. The main concern was not the issues of politics, powers and agencies in the sector, but that these issues continue to fall on 'deaf ears'. Many respondents reported a lack of government regulation, monitoring and control, and were often confused about the actual existence of any bodies with this regulatory remit. Whether or not this body exists may not be the real issue, but rather the apparent neglect of stakeholder communication. A useful proposition to government would be to establish a reliable channel of communication between itself and stakeholders of the ECCE Sector, resulting in improved quality of service provided by ECCE centres, as well as the prompt resolution of any issues and concerns raised. This would ensure that the work of any regulatory body established for ECCE would be well-informed and largely shaped by stakeholder participation.

\section{Recommendations}

The following are some of the recommendations with the hope that if put in place it will help in addressing problems of universal basic education in Nigeria:-

i. Adequate funding: The major problem facing basic education is inadequate funding of the program, government should ensure as a matter of urgency the meeting of the UNESCO threshold of $26 \%$ budgetary allocation to education in any member country.

ii. Private partnership: As a result of the enormous amount of funds involved in education, philanthropic organizations should as a matter of urgency be involved in funding basic education in Nigeria.

iii. The relationship between the three tiers of government with respect to funding basic education should be made clear with respect to who plays what role when and how as a matter of urgency. Government should enhance the autonomy of each and every tier of government especially state-local relations. The issue of joint account should be abolished.

iv. The commission should ensure proper record keeping of the income and expenditure of the primary schools.

v. In addition to that, government should ensure that the money meant for enhancement of primary education commission is spent judiciously in accordance to the laid down rules and regulations. This could be achieved through transparency and accountability.

\section{References}

Adenipekun, N. (2004).Young Children and Early Childhood Services. New York: Cambridge University Press.

Adesina, A. E. (2011). Perceived impact of primary education on the attainment of Nigeria vision 2020. Mediterranean journal of social sciences vol. 2 (5), 61-69.

Agagu, A.A. (2010). Republic polity instability and political instability in Nigeria $23^{\text {rd }}$ inaugural lecture, University of Ad-Ekiti, Nigeria. 
Crosser, S. (2016). "Managing the Early Childhood Classroom." In Young Children, London Frontage Publishers. Vol. 47 No. 2.

Estes (2004). Early Childhood Environmental Education: Making it Mainstream. Canberra. Early Childhood Australia.

Federal Republic of Nigeria (2016). National Policy on Education. Lagos, Federal Government Press.

Nwankwo, J. I. (2014). Management in education. Modern approaches in education management. Ibadan. Giraffe Books.

Oduolowu, N. and Olowe, H, (2011). Government expenditure and economic growth in Nigeria, 1970-2008. A disaggregated analysis. Business and economic journal 20 (10) 478-555.

Ogbonnaya, F. (2009). From Children's Services To Children's Spaces. Public Policy, Children and Childhood. New York.RoutledgeFalmer.

UNESCO. (1993). World Education Report 1993, UNESCO, Paris.

UNICEF (United Nations Children's Fund) (2003). The State of the World's Children, 2003. Child Participation. Retrieved 13 October 2005, from: http://www.unicef.org/sowc03/contents/pdf/SOWC03-eng.pdf. 